\title{
Simple and Divided Leaves in Ferns: Exploring the Genetic Basis for Leaf Morphology Differences in the Genus Elaphoglossum (Dryopteridaceae)
}

\author{
Alejandra Vasco ${ }^{1, *(D)}$ and Barbara A. Ambrose ${ }^{2, *(D)}$ \\ 1 Botanical Research Institute of Texas, 1700 University Drive, Fort Worth, TX 76107-3400, USA \\ 2 The New York Botanical Garden, 2900 Southern Blvd, Bronx, NY 10458-5126, USA \\ * Correspondence: avascog@gmail.com (A.V.); bambrose@nybg.org (B.A.A.); \\ Tel.: +1-817-546-1840 (A.V.); +1-718-817-8185 (B.A.A.)
}

Received: 1 May 2020; Accepted: 18 July 2020; Published: 22 July 2020

\begin{abstract}
Despite the implications leaves have for life, their origin and development remain debated. Analyses across ferns and seed plants are fundamental to address the conservation or independent origins of megaphyllous leaf developmental mechanisms. Class I KNOX expression studies have been used to understand leaf development and, in ferns, have only been conducted in species with divided leaves. We performed expression analyses of the Class I KNOX and Histone H4 genes throughout the development of leaf primordia in two simple-leaved and one divided-leaved fern taxa. We found Class I KNOX are expressed (1) throughout young and early developing leaves of simple and divided-leaved ferns, (2) later into leaf development of divided-leaved species compared to simple-leaved species, and (3) at the leaf primordium apex and margins. $\mathrm{H} 4$ expression is similar in young leaf primordia of simple and divided leaves. Persistent Class I KNOX expression at the margins of divided leaf primordia compared with simple leaf primordia indicates that temporal and spatial patterns of Class I KNOX expression correlate with different fern leaf morphologies. However, our results also indicate that Class I KNOX expression alone is not sufficient to promote divided leaf development in ferns. Class I KNOX patterns of expression in fern leaves support the conservation of an independently recruited developmental mechanism for leaf dissection in megaphylls, the shoot-like nature of fern leaves compared with seed plant leaves, and the critical role marginal meristems play in fern leaf development.
\end{abstract}

Keywords: Class I KNOX; Dryopteridaceae; Elaphoglossum; ferns; fronds; leaf diversity; leaf evolution and development; megaphyll

\section{Introduction}

Leaves are the dominant organ in most extant vascular plants and their evolutionary origin, likely in the early Devonian, fundamentally changed not only life on earth, but also the basic Bauplan of vascular plants [1,2]. Despite this profound importance, the number of times leaves have evolved in vascular plants is still debated, and it is mainly within Euphyllophytes (ferns and seed plants) that the number of times leaves have evolved is still not settled. In Euphyllophytes, leaves have been hypothesized to have evolved from one up to nine times [3-6]. Particularly in the ferns, there is currently no consensus on whether the leaves of major lineages such as the Equisetaceae (horsetails), Psilotaceae (whisk ferns), Ophioglossaceae, Marattiaceae, and the leptosporangiate ferns are homologous [7,8].

The leaves of the Euphyllophytes are also called megaphylls and are characterized by an enormous morphological diversity; they can be simple, lobed, pedate, digitate, or divided (also termed compound or dissected). The genetic developmental basis of this enormous diversity has been mainly studied in 
model angiosperms, but it is largely unknown in ferns. Comparative analyses across Euphyllophyte lineages are essential to gain the comparative data needed to resolve the long-standing questions of leaf evolution and development. Comparative approaches to understand the genetic pathway affecting megaphyll shape outside of angiosperms have mainly focused on the Class I KNOTTED1-like HOMEOBOX (Class I KNOX) genes [9-11].

In angiosperms, genetic studies have explored the basis for differences in leaf division in the species with simple leaves: Arabidopsis thaliana, Zea mays, and Antirrhinum majus, compared with species with divided leaves: Cardamine hirsuta, Lycopersicon esculentum, Pisum sativum, and Medicago truncatula [12-14]. In angiosperms, Class I KNOX proteins are generally necessary for meristem maintenance and are expressed throughout the vegetative and floral shoot apical meristems (SAMs) and down-regulated in leaf primordia and floral organs [14-21]. In angiosperms with simple leaves, Class I KNOX proteins are expressed in the SAM, and down-regulated in incipient leaf primordia and throughout primordium development $[14,17,20]$. In many angiosperms with divided leaves, Class I KNOX proteins are also expressed in the SAM and down-regulated in incipient leaf primordia; however, they are expressed later in young leaf primordia and in sites of leaflet initiation $[9,22]$. Class I KNOX expression and function in leaves have been shown to underlie divided leaf morphology in angiosperms $[9,22,23]$. In angiosperms with divided leaves, over-expression of Class I KNOX produces mature leaves that are highly divided [24-26]. Meanwhile, in plant species with simple leaves, an overexpression of Class I KNOX genes does not result in divided leaves, but leaves with lobes or crenulated margins $[17,24,27,28]$. Therefore, Class I KNOX genes are required, but not sufficient, to produce divided leaves in angiosperms $[9,29]$.

In gymnosperms, Class I KNOX expression has been reported for Picea abies (simple leaves) [30], Zamia floridans (divided leaves) [9], and Welwitschia mirabilis (simple leaves) [31]. These studies have shown that Class I KNOX are expressed in the SAM and down-regulated in incipient leaf primordia of simple and divided gymnosperms leaves, and up-regulated in divided leaved species. These patterns of expression are similar to those found in angiosperms, providing support for the homology of seed plant leaves.

For ferns, the expression profiles of Class I KNOX genes have been studied only in the species with divided leaves: Osmunda regalis [10], Anogramma chaerophylla [9], Ceratopteris richardii [32], and Elaphoglossum peltatum f. peltatum [33]. These studies showed that Class I KNOX genes are expressed in the fern's SAM, in young leaf primordia, and in the margins of old leaf primordia, similar to seed plants; but unlike in most seed plants, Class I KNOX genes were found not to be down-regulated in incipient leaf primordia of ferns with divided leaves [9,32]. This lack of down-regulation has been interpreted either as leaves of ferns and seed plants having evolved independently [9], or as a reflection of the delayed determinacy (i.e., persistent meristematic activity) exhibited by fern leaves [10]. However, Class I KNOX expression in the margins of old leaf primordia in fern species with divided leaves suggests that the same network for divided leaf development might be conserved in ferns and seed plants $[9,10,32]$. Central to resolving this debate are ferns with simple leaves, whose Class I KNOX expression patterns have not been studied before. The expression of Class I KNOX in simple leaves in ferns will help to better understand if the differences in expression found between ferns and angiosperms are linked to leaf morphology or if they can explain the different evolutionary origins of fern and seed plants leaves. Such a comparative approach is fundamental to address questions about the conservation or independent origins of megaphyllous leaf developmental mechanisms in plants.

Among leptosporangiate ferns, Elaphoglossum is one of the most diverse genera of ferns and its nearly 600 species are characterized by simple entire leaves [34]. There are only six species of Elaphoglossum that have divided leaves and four of them belong to a monophyletic group of 20 species, Elaphoglossum section Squamipedia [35-37]. The species with divided leaves belonging to section Squamipedia are E. colombianum (Maxon) Mickel, E. moorei (E. Britton) Christ, E. peltatum (Sw.) Urban, and E. tripartitum (Hook. \& Grev.) Mickel (Figure 1a). Phylogenetic molecular studies have shown that, within section Squamipedia, the four species with divided leaves are not monophyletic and instead have 
had independent evolutionary origins from ancestors with simple, entire leaves [36] (Figure 1a). This suggests that the four species with divided leaves in section Squamipedia represent four independent reversions or new acquisitions of the divided condition [36,38], providing a fascinating system to study the evolution and development of leaf division in ferns within a robust phylogenetic framework.
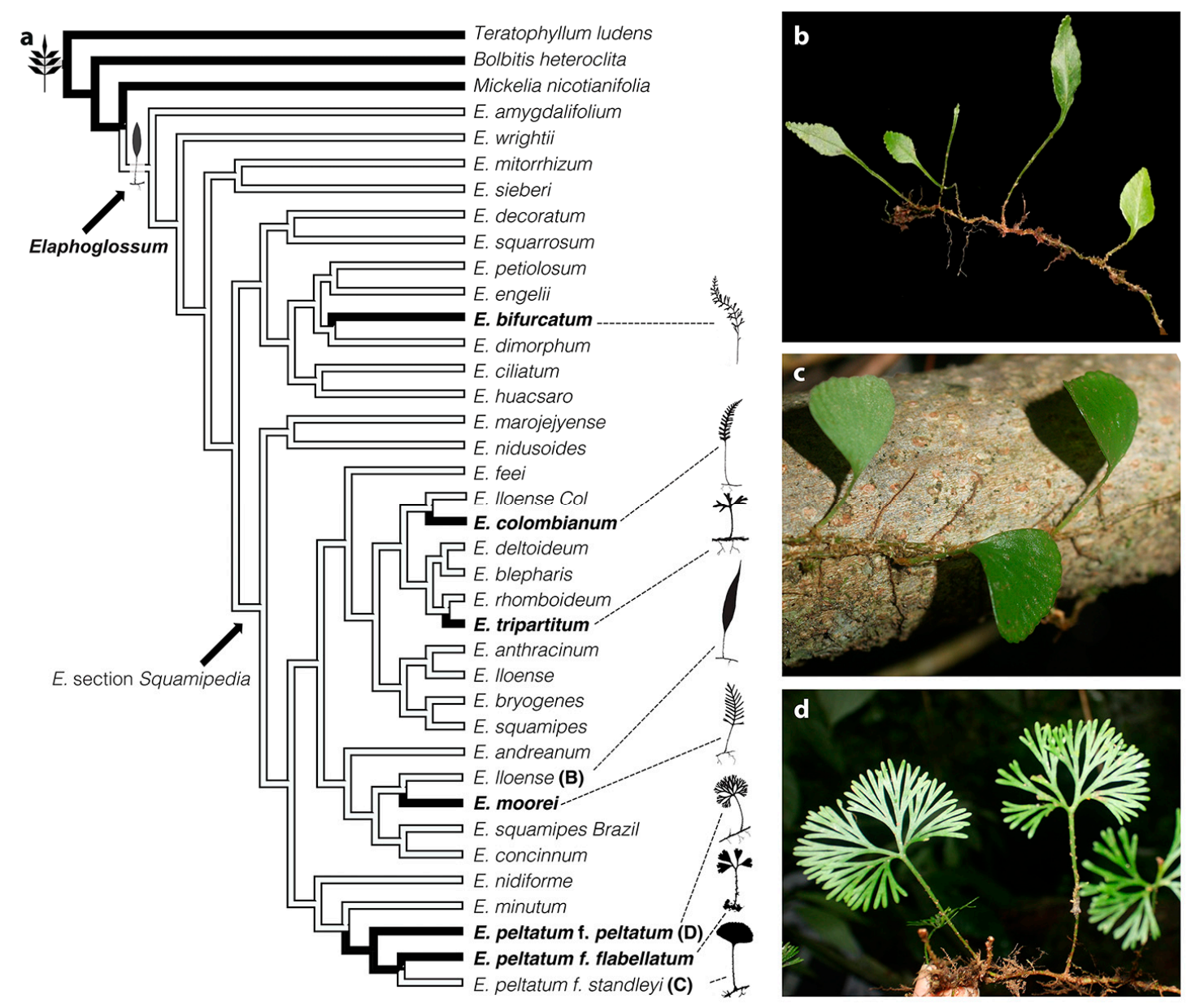

Figure 1. Leaf morphological variation in the genus Elaphoglossum. (a) Phylogeny of Elaphoglossum with leaf dissection optimized onto the tree (characters were optimized under a parsimony criterium with Mesquite V. 3.5). Black branches = divided leaves, white branches = simple leaves (modified from [36]). Divided-leaf taxa are in bold and displayed as shadow diagrams (not to scale), and the letter after species indicates species included in the expression studies. (b-d) The three closely related taxa studied of Elaphoglossum section Squamipedia. (b) Elaphoglossum lloense (simple leaves). (c) Elaphoglossum peltatum f. standleyi (simple leaves). (d) Elaphoglossum peltatum f. peltatum (divided leaves).

To better understand the genetic and developmental basis underlying fern leaf morphological diversity and to compare this with what is known for ferns and seed plants, we isolated Class I KNOX orthologs from ferns, investigated their evolution, and studied their expression in three taxa with different leaf morphologies belonging to Elaphoglossum section Squamipedia (Figure 1). We also used the expression of Histone $\mathrm{H} 4$ to better understand the leaf development of fern species with simple and divided leaves. $\mathrm{H} 4$ genes have been previously used to assay cell-cycle activity in lateral organs and, as such, they can be used as a cellular division marker [22,39].

The selected three taxa were as follows: Elaphoglossum lloense (Hook.) T. Moore with simple, entire leaves, typical of most species within the genus (Figure 1b); Elaphoglossum peltatum $\mathrm{f}$. standleyi (Maxon) Mickel with simple leaves that are circular to lunate (Figure 1c); and E. peltatum f. peltatum, with divided leaves cleaved medially into two halves, where the two halves are divided subdichotomously 
up to seven times (Figure 1d). Elaphoglossum peltatum and its forms (two of them included in this study, forma standleyi and forma peltatum) have perplexed taxonomists for years [36,40-44]. Several authors have considered these forms as different species and not as merely phenotypic variants, because they appear quite distinct from each other and may even grow intermixed and maintain their distinctness. However, recent studies considered them as different forms of the same species, because examination of herbarium specimens reveals many intermediates among all the forms and because phylogenetic studies recover all three forms as part of the same clade, but not reciprocally monophyletic $[35,36]$.

By studying these three closely related fern taxa with different leaf morphologies, two with simple leaves, we wanted to better understand if the leaf developmental genes and their expression are conserved among ferns and angiosperms with different leaf morphologies, and if differences in the patterns of expression of Class I KNOX genes correlate with different fern leaf morphologies.

\section{Results}

\subsection{Evolutionary History of Class I KNOX Transcription Factors in Ferns}

To gain a more detailed evolutionary history of Class I KNOX in ferns and to discover the putative Elaphoglossum Class I KNOX gene copies for our expression studies, we isolated putative homologs from selected species spanning the phylogeny of ferns, and all three orders of lycophytes by PCR and database mining (Appendix A). We identified 13 new sequences by PCR. The final analyzed matrix included 53 sequences, of which 22 belonged to ferns. The aligned matrix had 732 nucleotide and 244 amino acid characters and included the four domains encoded by KNOX genes (KNOX1, KNOX2, ELK, and TALE-HD). The final data set is deposited in figshare (10.6084/m9.figshare.12576581). Analyses of the nucleotide and amino acid sequences yielded congruent tree topologies. The phylogenetic relationships found are presented as majority-rule consensus trees, including branch lengths and posterior probability values for nodes (Figure 2).

Lycophyte sequences are not recovered as monophyletic, but in four different clades successively sister to euphyllophytes. Each lineage of Lycophytes, Selaginellales, Lycopodiales, and Isoetales, has at least two copies of Class I KNOX. Fern sequences form a monophyletic group sister to all seed plant Class I KNOX genes. During the evolution of ferns, at least two major duplication events are inferred (Figure 2, arrows), thus ferns have at least three copies of Class I KNOX genes. One copy (Copy 3 in Figure 2), which is sister to the other two, consists exclusively of sequences from the heterosporous ferns (order Salviniales). The other two copies of ferns Class I KNOX are sister to each other and include all the major lineages of ferns. The two Class I KNOX copies previously reported for the fern Ceratopteris richardii (CrKNOX1 and CrKNOX2; Sano et al., 2005) belong to Fern Class I KNOX Copy 1 (Figure 2).

For two of our study species, Elaphoglossum peltatum f. peltatum (divided leaves) and E. peltatum f. standleyi (simple leaves), our mining for KNOX genes using degenerate primers recovered Copy1 and Copy 2 of ferns Class I KNOX (EppC1KNOX1, EppC1KNOX2, EpsC1KNOX1, and EpsC1KNOX2, Figure 2); for E. lloense (simple leaves), we only recovered Copy 2 (EllC1KNOX2, Figure 2). We found that all these Elaphoglossum Class I KNOX genes are recovered in a clade sister to all the well-known Class I KNOX angiosperm genes (Figure 2). Comparison of both Class I KNOX copies does not indicate that they are differentially spliced (Figure S1). 


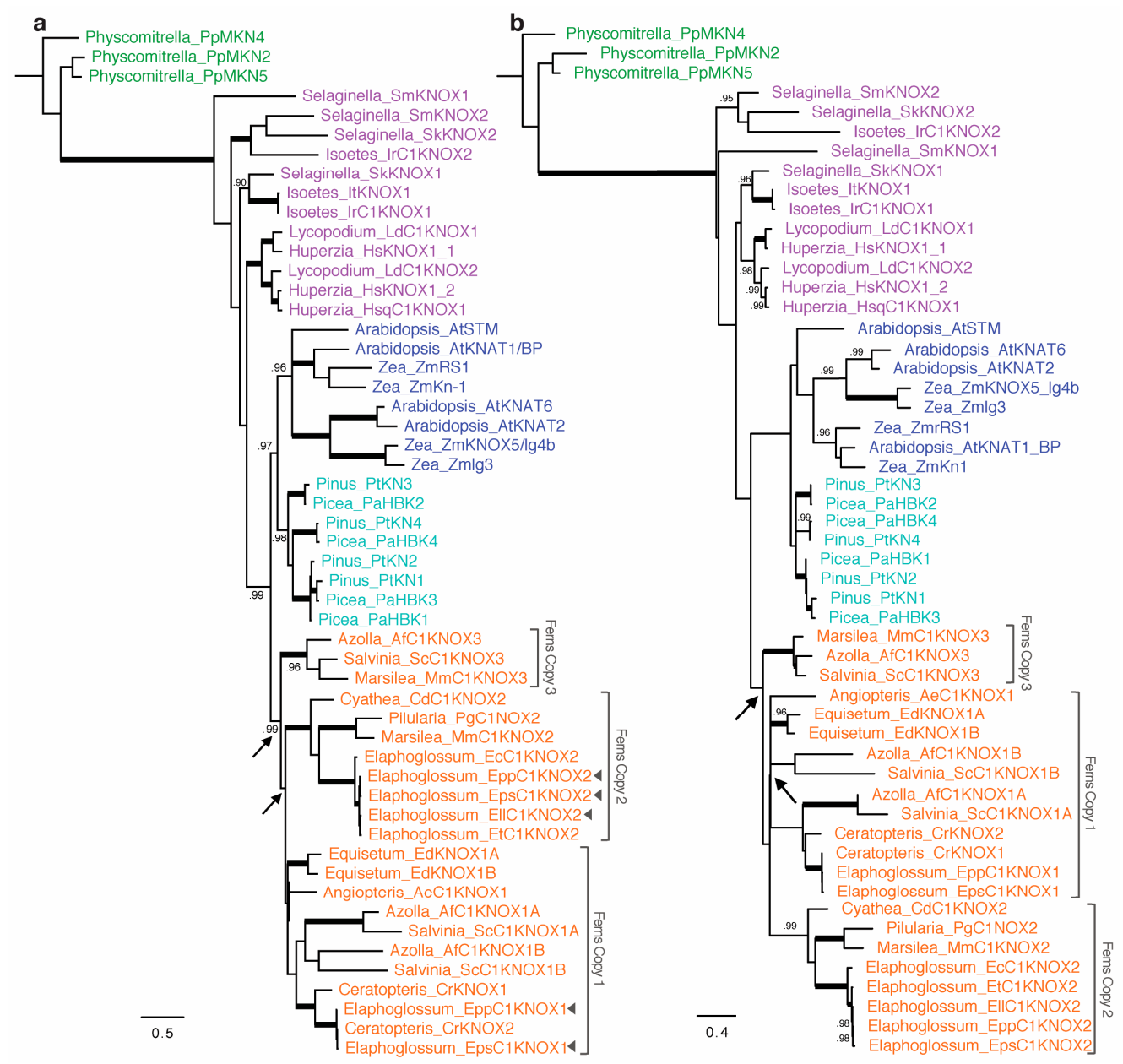

Figure 2. Phylogeny and evolution of Class I KNOX genes in ferns. (a,b) Phylograms inferred with (a) nucleotides and (b) amino acids presented as majority-rule consensus trees recovered in Bayesian inference (BI) analysis, including branch lengths and posterior probability (PP) values for nodes. Thick branches indicate $\mathrm{PP}=1$. PP values below 0.90 are not displayed. Colors of clade names correspond to the sources of the genes: green, bryophytes; purple, lycophytes; orange, ferns; light blue, gymnosperms; dark blue, angiosperms. Species abbreviations are listed in Appendix A. Arrowheads in (a), genes used for in situ hybridization analyses; arrows, inferred duplications within ferns.

\subsection{Development of Simple and Divided Leaves of Elaphoglossum}

One characteristic typical of most fern leaves is their coiled young emerging leaves. Those have been referred to as crosiers or fiddleheads. Just as the whole leaf is coiled in bud, so too are its subdivisions, the pinnae and/or pinnules. Presumably, the function of coiling is to protect the soft meristematic parts concealed within the fiddlehead. Fiddleheads are highly distinctive of ferns because they are absent from lycophytes and nearly all seed plants [7].

The three Elaphoglossum species studied here have long creeping stems (Figure 1b-d). Leaves are distichous (two vertical columns on opposite sides of the stem), alternate, and distant. Leaf primordia develop and grow slowly compared with the stem elongation rate, which is why in our studied species there is a relatively long distance among the visible developing leaves. In general, when plants are in the field growing with sufficient space and humidity, leaves only start to uncoil after the sixth visible leaf (Vasco, pers. Obs.). Delayed leaf expansion seems to be a characteristic of ferns with long creeping stems (Vasco, pers. Obs). Many studies of leaf development label leaves using plastochron numbers. Using a similar terminology for this study was not possible, mainly because of the delayed leaf expansion as described. Here, we defined five developmental stages based on leaf primordium 
morphology following our observations of histological sections and previously published fern leaf morphological and anatomical analyses [45-49] (Figure 3).

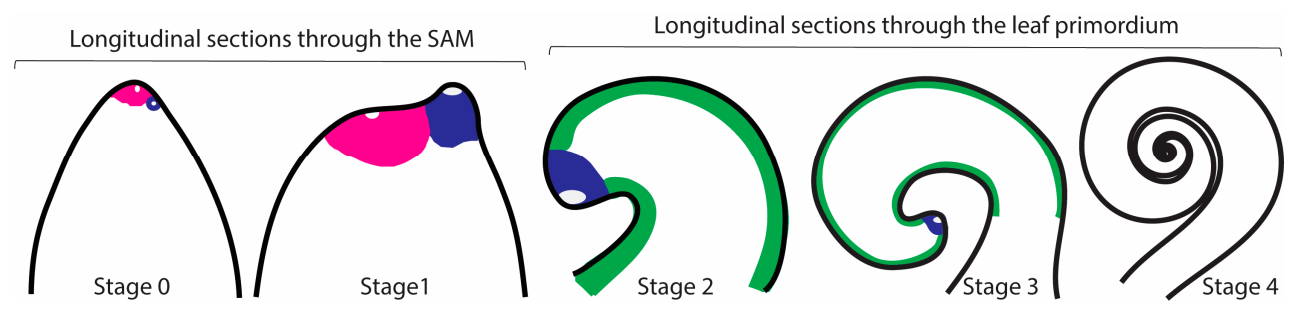

Figure 3. Stages of leaf development in the studied ferns and the meristems involved (pink = SAM, blue $=$ LAM, green $=\mathrm{MM}$ ). Stage 0 (leaf initiation) Leaf initiation begins with the enlargement of an epidermal cell close to the shoot apical meristem. Stage 1 (early leaf development): the leaf primordium is a protrusion that is more or less circular in outline; it has a prominent leaf apical initial (LAI). The LAI cuts off two files of cells that will become the marginal meristem (MM). Anatomically, the leaf apical meristem (LAM) resembles the shoot apical meristem (SAM). Stage 2 (middle leaf development): the apex of the leaf primordium is clearly curved with an apparent LAI and MM. Basipetal procambium development is apparent. Stage 3 (late leaf development): the apex of the leaf primordium apex is extremely curved towards the shoot apex owing to more cell divisions on the abaxial side. Stage 4 (late crosier formation; pinna emergence): the crosier is apparent and the LAI is the same size as the rest of the cells and no longer dominant; in divided leaves, acropetal development of pinnae is apparent (not shown). Different stages not to scale. White regions in the SAM and LAM indicate leaf apical initial/s.

All leaves from the three Elaphoglossum species studied arise as lateral organs from the flank of the SAM. Leaf initiation (Stage 0) is detected by the enlargement of a superficial cell on the flank of the SAM. The morphology of leaf primordia of species with simple and divided leaves appears similar from Stages 0-2; all primordia are simple, and no outgrowths are detectable in both simple and divided leaved species (Figures 4 and 5). All leaf primordia are characterized by the presence of an enlarged cell at the apex - the leaf apical initial (LAI), surrounded by small cells forming a wedge shape around it, together comprising the leaf apical meristem (LAM) (LAI clearly seen in Figure $4 b, c, f, g, j$ and Figure $5 c, g, k, l)$. In Stage 3 of leaf development, the apex of the leaf primordium apex is extremely curved towards the shoot apex (Figure 4c,l). In Stage 4 of development, in species with divided leaves, subdivisions are detectable in the apical portion of the leaf primordium, but the primordium and its pinnae are still coiled (Figure 5n).

\subsection{Patterns of Cell Division in Simple and Divided Leaves of Elaphoglossum}

Generally, the first approach to study leaf development is to look at leaf primordia at different stages of development under a scanning electron microscope (SEM). In our studied species, this approach was not feasible owing to the presence of scales, which develop early, are large, and are copious around the SAM and leaf primordia (Figure S2). Instead, to better understand the patterns of cell division in developing simple and divided leaves of the three closely related species of Elaphoglossum with diverse leaf morphologies, we used in situ hybridization analyses of the $\mathrm{H} 4$ genes. Using degenerate primers, we recovered one copy of $\mathrm{H} 4$ for each of the three studied species (EllH4, EppH4, EpsH4, Appendix B).

We found that $\mathrm{H} 4$ is expressed in punctate patterns during Stage 1 (Figure 4e,j) and Stage 2 (Figure $4 \mathrm{~b}, \mathrm{f}, \mathrm{g}, \mathrm{k}$ ). In these developmental stages, the $H 4$ expression pattern is similar in species with simple and divided leaves, suggesting that cell divisions in young leaf primordia are similar, occurring randomly throughout the primordium and infrequently in the LAI, but more frequently in the cells surrounding the LAI. In primordia of species with simple and divided leaves, $H 4$ expression in Stage 3 is detected in the apical region behind the LAI and in the procambium (Figure 4c,l). However, at Stage 3, in the species with simple leaves, $\mathrm{H} 4$ expression along the margins is continuous (Figure 4c), while H4 expression in divided leaves is discontinuous in the abaxial side, being detected in discrete regions of the leaf margins (Figure 4l). Although $\mathrm{H} 4$ expression is clearly different at Stage 3 between species with 
simple and divided leaves, morphologically, these primordia are indistinguishable (compare Figure 4c with Figure 41). Transverse sections of Stage 4 leaf primordia of simple and divided developing leaves show little expression of $\mathrm{H} 4$ in the petiole and random expression in the lamina (Figure $4 \mathrm{~h}, \mathrm{~m}$ ).

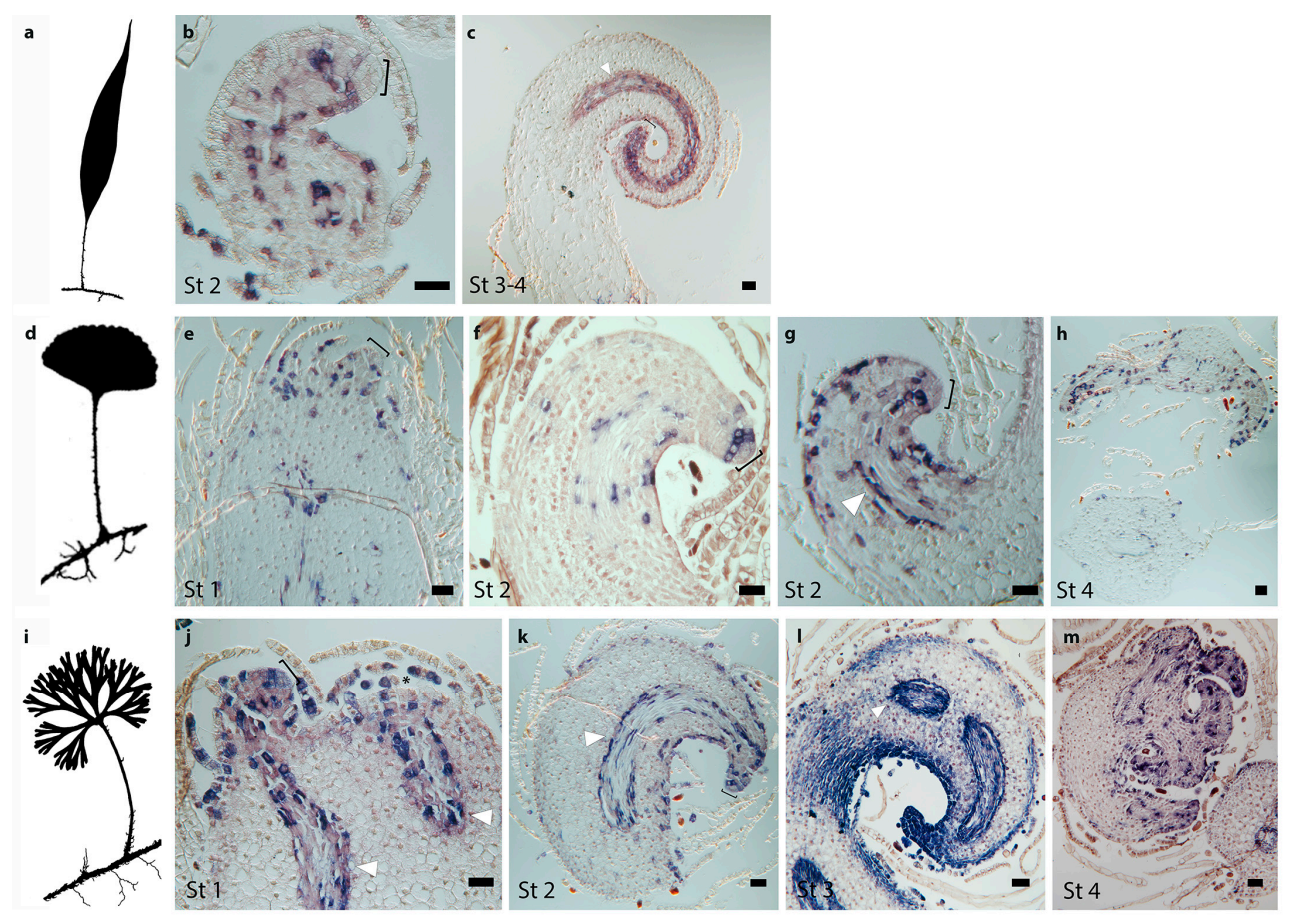

Figure 4. Cell division patterns as indicated by expression of Histone H4 genes during leaf development in species of the fern genus Elaphoglossum with simple and divided leaves. (a-c) Elaphoglossum lloense (simple leaves). (b,c) Expression patterns of $E l H 4$, longitudinal sections through the leaf primordium. (b) Expression in cells surrounding the leaf apical initial (LAI) and random cells throughout the primordium. (c) Expression in the apical region behind the LAI, in the procambium, and in the apical region of the margins. (d-h) Elaphoglossum peltatum f. standleyi (simple leaves). (e-h) Expression patterns of EpsH4. (e-g) Longitudinal sections through the shoot apical meristem (SAM) and/or leaf primordium. (e) Expression in random cells throughout the primordium that do not include the LAI. (f) Expression in the apical region right behind the LAI and in random cells throughout the primordium. (g) Expression in the apical region behind the LAI, in the procambium, and in cells of the margins. (h) Transverse section of old developing leaf, little expression in petiole and random expression throughout the lamina. (i-m) Elaphoglossum peltatum f. peltatum (divided leaves). (j-m) Expression patterns of EppH4. (j-1) Longitudinal sections through the SAM and/or leaf primordium. (j) Expression in the apical region including the LAI and in random cells throughout the primordium. (k) Expression in the apical region behind the LAI, in the procambium, and in cells of the margins. (l) Expression in the apical region, the procambium, and the margins; expression is discrete on the adaxial margin. (m) Transverse section of old developing leaf, little expression in petiole and random expression throughout the lamina. St, leaf developmental Stages following Figure 3; asterisk, SAM; brackets, LAI; white arrowhead, procambium. Bars $=40 \mathrm{um}$.

\subsection{Class I KNOX Gene Expression Patterns in Simple and Divided Leaves of the Fern Genus Elaphoglossum}

To better understand the molecular genetic basis underlying fern leaf morphological diversity and to compare our data with what is known for other ferns and seed plants, we used in situ hybridization to determine whether changes in gene expression correlate with changes in leaf morphology in the species with simple and divided leaves of our study group in the genus Elaphoglossum (Figure 1). We compared and analyzed the expression profiles of two of the fern copies of the meristem maintenance Class I KNOX genes (orthologous to all the well-known Class I KNOX angiosperm genes) specific to Elaphoglossum lloense (simple leaves, only EllC1KNOX2 copy), E. peltatum f. peltatum (divided leaves, 
EppC1KNOX1, EppC1KNOX2), and E. peltatum f. standleyi (simple leaves, EpsC1KNOX1, EpsC1KNOX2) (Figure 2 arrow heads).

We found that, in our studied species of Elaphoglossum, patterns of expression of both Class I KNOX copies are similar to each other throughout leaf development (compare patterns of expression in Figure 5 with Figure S3). Class I KNOX genes are expressed throughout the entire apical dome of the shoot meristem and the procambium regardless of leaf morphology (Figure $5 b, f, k, l)$. Interestingly, we found evidence that indicates Class I KNOX are downregulated in incipient leaf primordia in at least one of the species with simple leaves (Figure $5 b$ ). Because fern roots develop in the stem just beneath the leaf primordium [50], we also detected Class I KNOX expression at developing roots, likely at the root apical meristem (RAM) (Figure S3).
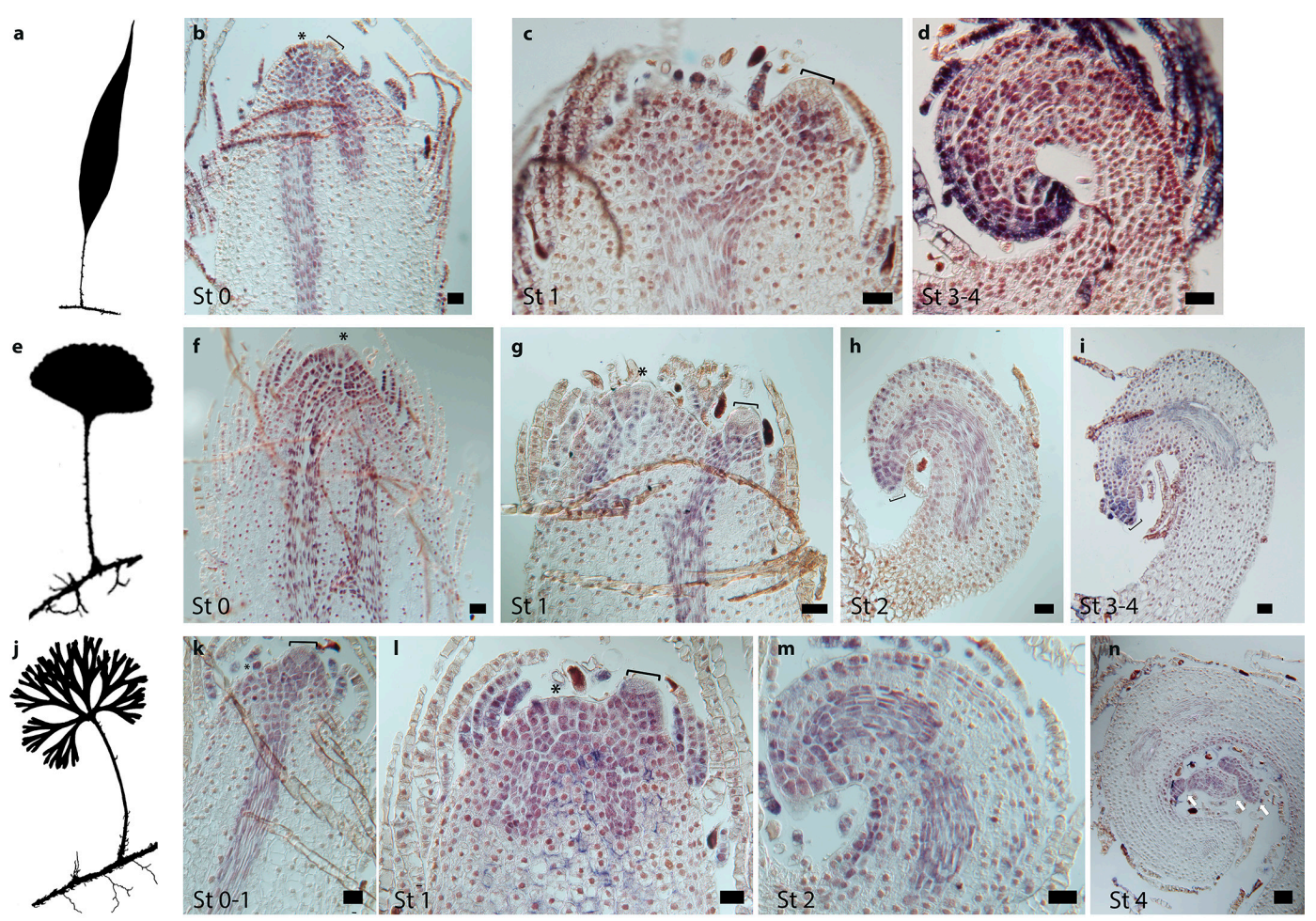

Figure 5. Expression patterns of Class I KNOX genes during leaf development in species of the fern genus Elaphoglossum with simple and divided leaves, longitudinal sections through the shoot apical meristem (SAM) and/or leaf primordia. (a-d) Elaphoglossum lloense (simple leaves). (b-d) Expression patterns of EllC1KNOX2. (b) Expression throughout the entire apical dome of the SAM and procambium, expression lacking from the incipient leaf primordium. (c) Expression throughout the entire young leaf primordium, lacking from the LAI. (d) Expression in the apical region, procambium, and the margins distally particularly abaxially. (e-i) Elaphoglossum peltatum $\mathrm{f}$. standleyi (simple leaves). (f-i). Expression patterns in E. peltatum $\mathrm{f}$. standleyi of (f-h) EpsC1KNOX2 and (i) EpsC1KNOX1. (f) Expression throughout the entire apical dome of the SAM and procambium. (g) Expression in the SAM, procambium, and throughout the entire young leaf primordium, lacking from the LAI. (h) Expression in the apical region, procambium, and the margins, lacking from the LAI. (i) Expression in the apical region including the LAI and in the procambium; expression is absent from the margins. (j-n) Elaphoglossum peltatum $\mathrm{f}$. peltatum (divided leaves). (k-n) Expression patterns of EppC1KNOX2. (k) Expression throughout the entire apical dome of the SAM and procambium, including the incipient leaf primordium. (1) Expression throughout the entire apical dome of the SAM, procambium, and throughout the entire young leaf primordium, lacking from the LAI. (m) Expression in the apical region, procambium, and margins; expression is discrete on the adaxial margin. (n) Expression in the apical region where pinnae are developing (white arrows), procambium, and adaxial margin. St, leaf developmental stages following Figure 3; asterisks, SAM; brackets, LAI. Bars $=40 \mathrm{um}$, (except $\mathrm{n}=80 \mathrm{um}$ ). 
In E. lloense and E. peltatum f. standleyi, the species with simple leaves, Class I KNOX are expressed throughout the entire young leaf primordium (not including the LAI) at Stage 1 (Figure 5c,g). This expression is maintained throughout Stage 2 in the leaf apical region (including the LAI), procambium, and in the margins (Figure 5h). Later in development, in Stages 3 and 4, Class I KNOX expression is restricted to the leaf primordium apical region, procambium, and it starts disappearing or it is absent from the margins (Figure $5 \mathrm{~d}, \mathrm{i}$ ).

In E. peltatum f. peltatum, the species with divided leaves, Class I KNOX are expressed throughout the entire young leaf primordium (not including the LAI) at Stage 1 (Figure 5k,l). This expression is maintained throughout Stage 2 in the leaf apical region (including the LAI), the procambium, and in a discontinuous pattern in the margins (Figure $5 \mathrm{~m}$ ). Later in development in Stage 4, when divisions are evident at the apical region in older leaf primordia of the species with divided leaves, Class I KNOX expression is detected at the apical region and developing divisions, in the procambium, and in the margins of the leaf primordium adaxially (Figure 5n).

\section{Discussion}

\subsection{Evolutionary History of Class I KNOX Transcription Factors in Ferns}

Our results showed that, within vascular plants, Class I KNOX lycophyte sequences are recovered in four different clades, successively sister to euphyllophytes, and not reciprocally monophyletic (Figure 2). The non-monophyly of lycophyte sequences might suggest ancient duplication events of the only inherited Class I KNOX gene in the ancestor of all vascular plants, or it might be the result of high rates of evolution combined with limited sequence data (see $[51,52]$ for similar results in different gene phylogenies). Further analyses of additional lycophyte genomes are necessary to better understand the evolutionary history of Class I KNOX in lycophytes and their relationship with those of other vascular plants.

Our phylogenetic hypothesis recovered fern sequences as a monophyletic group sister to Class I KNOX genes of seed plants, which suggests that all fern sequences are putative orthologs to the one known Class I KNOX seed plant lineage. Although additional expression analyses using RNAseq techniques might reveal additional Class I KNOX copies in certain fern groups, we found ferns have at least three copies of Class I KNOX genes (Figure 2). The ferns Class I KNOX Copy3, which is recovered sister to the other two, was found exclusively in sequences of the water fern order Salviniales (sensu [53]). Two of those ferns, Azolla filiculoides and Salvinia cucullata, correspond to the family Salviniaceae and are the only fern species whose genomes are currently sequenced and publicly available [54]. The other sequence corresponds to Marsilea minuta in the family Marsiliaceae and was revealed during our mining for KNOX genes using degenerate primers. Salviniaceae and Marsiliaceae, which are sister families, not only predominantly grow in water, but also are the only ferns that are heterosporic [53]. Although further genome sequencing may reveal additional fern taxa that have the Class I KNOX Copy3, it is also possible that this copy may be restricted to heterosporic ferns and play a role in heterospory.

The other two copies of fern Class I KNOX found, Copy1 and Copy2, are sister to each other and show phylogenetic relationships largely consistent with recently published fern species phylogenies $[53,55,56]$, suggesting the two copies diversified during the evolution of ferns (Figure 2). Obtaining representative fern genomes and conducting further comparative analyses of the evolutionary history of different gene families will be important to determine if the duplication that led to Copies 1 and 2 of Class I KNOX genes in ferns was the result of the whole-genome duplication predating the core Leptosporangiate ferns inferred by Li et al. [54] or of another mechanism of gene duplication.

\subsection{Class I KNOX Genes Are Expressed in Shoot and Leaf Fern Meristems}

Developmentally, both seed plant and fern leaves (megaphylls) arise as lateral organs from the flank of an indeterminate SAM in a distinct phyllotaxy, have adaxial/abaxial identities, and are determinate 
organs. Fern leaves, however, differ from seed plant leaves in several aspects. Morphological and anatomical studies have shown that, in general, development of the fern leaf is from the leaf apical meristem (LAM) and the marginal meristem (MM). The LAM is composed by a leaf apical initial (LAI) and its derivatives, the LAI is an enlarged cell located at the tip of the fern leaf primordium [57-59]. The MM is located at the periphery of developing leaf primordia and is composed of marginal and submarginal initials and has been argued to be organized similar to a SAM [49,57,60-63]. In ferns, the MM makes a major contribution to lamina formation, and remains active until the general morphology of the leaf is established and the location of all procambium has been determined [47,62,64].

Class I KNOX proteins in angiosperms have been shown to be generally necessary for meristem maintenance [14-21]. We found Class I KNOX expression in the SAM, LAM, and RAM of ferns with simple and divided leaves (Figure 5 and Figure S3). We also found Class I KNOX expression in the margins in the early development of simple and divided leaved Elaphoglossum species (Figure 5). The Class I KNOX expression in the margins of fern leaf primordia reflects the persistent meristematic activity of the $\mathrm{MM}$ and the interpretation of the fern leaf margin as a region of sustained meristematic activity $[47,49,63]$.

\subsection{Class I KNOX Gene Expression in Fern Leaves Recapitulates Shoot Expression}

Compared with angiosperms, fern leaves have longer meristematic activity and maturation toward the apex $[65,66]$. This has been explained by the presence in fern leaf primordia of the LAM (LAI and derivatives) [57-59]. Angiosperm leaves do not have apical initials and, contrary to ferns, leaf growth is not limited to the apex and margins; instead, it can be diffuse with meristematic activity throughout the developing leaf, with some angiosperms having an intercalary meristem and plate meristem that give rise to most cells of the lamina [45].

Anatomical and experimental studies have demonstrated that fern leaf primordia have shoot-like characteristics, transitioning later to determinate fate when compared with angiosperms [65-72]. The persistent Class I KNOX expression we found at the LAM (LAI and surrounding cells) of developing leaves in the three species of Elaphoglossum supports these anatomical and experimental studies and agrees with previous findings of other comparative genetic studies $[9,73,74]$. Studies of angiosperm species with divided leaves, such as tomato, have considered divided leaves more shoot like, and this was reflected by persistent Class I KNOX expression in the leaves [25].

Class I KNOX genes are expressed in the SAM of ferns [9,32,33]. Our previous study, concentrated on Class I KNOX expression in the shoot apical fern meristem, found expression throughout the shoot apical dome (apical initial and surrounding cells) and reported that, in $40 \%$ of the experiments, expression of Class I KNOX was not detected in the shoot apical initial [33]. We found that this pattern of expression is recapitulated in the LAM of both simple and divided leaves of ferns, with expression detected at the apical portion of the leaf primordium throughout development but captured in the LAI intermittently (Figure 5). The recapitulated Class I KNOX expression in the SAM and in the LAM of leaf primordia of both simple and divided leaves in ferns, suggest that a similar developmental mechanism is present during development in fern shoots and fern leaves, giving further genetic and molecular support for the shoot-like nature (persistent meristematic activity) of fern leaves compared with seed plants leaves. Our findings support the partial shoot theory of leaf evolution proposed by Arber $[75,76]$, who considered the shoot to be the fundamental organ of the plant, and that all leaves were partial shoots because their indeterminate growth and radial symmetry are repressed.

\subsection{Development of Simple and Divided Leaves in Ferns}

Anatomical and morphological studies of fern leaf development have shown that primary fern leaf primordium development is owing to the growth and divisions of the LAM and the MM $[57,60,61,63]$. The patterns of $H 4$ expression we found in simple and divided leaves support these findings and suggest that, regardless of final morphology, cell divisions in early developing leaf primordia are similar in ferns (Figure 4). 
The expression patterns of Class I KNOXs we found at Stages 0-2 of leaf development are also similar in the three species of Elaphoglossum, suggesting that Class I KNOX expression is necessary for leaf development, but that early Class I KNOX expression cannot explain the morphological differences between simple and divided leaves in ferns (Figure 5). Only later in leaf development (Stages 3 and 4) does Class I KNOX expression and cellular division patterns ( $H 4$ expression) change between simple and divided leaves (Figures 4 and 5). Notably, at Stages 3 and 4, the expression of Class I KNOX persisted at the margins of leaf primordia of species with divided leaves (even after divisions develop) compared with species with simple leaves (Figure 5i,n). This persistent expression in the species with divided leaves compared with simple leaves indicates that temporal and spatial patterns of expression of Class I KNOX genes correlate with different fern leaf morphologies. This suggests that, although Class I KNOX alone is not sufficient to promote divided leaf development in ferns, Class I KNOX genes might contribute to the morphological variation between simple and divided leaves in ferns, as has been shown for angiosperms [22].

Previous anatomical and ontogenetic studies have suggested that, in leaf primordia of ferns with divided leaves, the LAM (LAI and derivatives) remains active and divisions occurred when the MM becomes interrupted in a regular manner, and some regions lose their meristematic potential $[47,57,60,61,63,64,73]$. The Class I KNOX expression in the margins of leaf primordia of ferns with simple and divided leaves highlights the critical role marginal meristems play in leaf development in ferns. Interestingly, both of our studied species with simple leaves have similar Class I KNOX expression patterns, even though the simple leaved E. peltatum $\mathrm{f}$. standleyi is only a different form of the same species as the divided leaved E. peltatum f. peltatum [35].

Notably, we detected down-regulation of Class I KNOX in incipient leaf primordia in one of the Elaphoglossum species with simple leaves (Figure 5b), but not in the divided leaved species (Figure 5k and Figure S3c). Although a lack of downregulation at Stage 0 in fern species with divided leaves has also been reported before [9], it could be that this precise developmental stage is difficult to capture in fern leaf development or that there is a difference in downregulation of Class I KNOX between species of ferns with simple and divided leaves.

\subsection{A Conserved Mechanism of Leaf Dissection in Megaphylls}

Class I KNOX expression and function in leaf primordia of angiosperms has been shown to underlie leaf morphology differences in angiosperms [9,22,77]. In angiosperms with simple leaves, Class I KNOX are only expressed in the SAM, and down-regulated in incipient leaf primordia and in mature leaves $[14,17,20]$. Whereas, in most angiosperms with divided leaves, Class I KNOX are expressed in the SAM, down-regulated in incipient leaf primordia, expressed throughout the young leaf primordia, and expressed in sites of leaflet initiation in older leaf primordia $[9,22]$. A notable exception is the divided leaved species of tomato, where down-regulation of Class I KNOX in P0 has not been found $[24,25]$.

We found a fundamental difference in leaf development in the Class I KNOX expression patterns between ferns and seed plants with simple leaves. In ferns with simple leaves, contrary to what has been reported for most angiosperms, Class I KNOX are expressed early in leaf development and maintained in the apical region of the developing leaf (Figure 5). On the other hand, similar to angiosperms with divided leaves, we found that, in ferns with divided leaves, Class I KNOX are expressed throughout the young leaf primordium and that this expression persists at the margins of leaf primordia (Figure 5). Moreover, in ferns with divided leaves, Class I KNOX expression persists in the apical region of the leaf primordium until very late in development. It has been shown that Class I KNOX expression in leaves was independently recruited to control divided leaf development in multiple seed plant lineages [9]. Our Class I KNOX expression data in a fern with divided leaves suggest that this genetic mechanism might have also been independently recruited in ferns to control divided leaf development. 
In angiosperms, there are several proteins and hormones known to act in the Class I KNOX pathway that affect leaf shape, including the proteins belonging to the NO APICAL MERISTEM/CUP-SHAPED COTYLEDON (NAM/CUC) and ASYMMETRIC LEAVES/ROUGH SHEATH2/PHANTASTICA (ARP) families of transcription factors, that are known to be redeployed to make leaflets in a divided leaf [29,78-81]. The complex patterns of Class I KNOX expression we found in all our studied fern species, and the persistent Class I KNOX expression in leaf margins and divisions of species with divided leaves compared with the species with simple leaves, could also be mediated by auxin maxima that are generated by PIN1, an auxin efflux transporter [22,29,82,83], as well as changes in protein partners such as members of the NAM/CUC family of transcription factors that maintain Class I KNOX expression in a positive feedback loop in the SAM and within divided leaves for leaflet formation $[77,79,84]$. Phylogenetic, expression, and functional studies of these genes in all the major lineages of vascular plants will be important to fully understand to what extent the developmental genetic network underlying megaphyll morphological diversity is conserved in Euphyllophytes (ferns and seed plants).

\subsection{Class I KNOX Genes and Megaphyll Evolution}

The homology of megaphylls is still highly debated, and even within the ferns, it is not clear if leaves are homologous [5,7]. Previous comparative studies have come to different conclusions about the conservation of a leaf developmental network between ferns and seed plants $[9,10,52,85,86]$. Conservation in a leaf developmental program across ferns and seed plants was suggested by comparative expression studies of two leaf developmental genes, Class I KNOX and Class III HD-Zip [10,52]. The Class I KNOX downregulation in leaf primordia of fern species with simple leaves we reported here, along with the other similarities in Class I KNOX expression between angiosperms and ferns (SAM and margins of leaf primordia in species with divided leaves, Figure 5), supports the hypothesis of a conservation in a leaf developmental program across ferns and seed plants, suggesting an independent co-option of a common ancestral mechanism for leaf development.

Overexpression and complementation studies in angiosperms suggest that Class I KNOX homologs from ferns can provide some of the same functions as endogenous angiosperm genes [10,32]. However, a recent comparative study across ferns showed differential expression of another leaf transcription factor, Class III HD-Zip in the SAM of ferns, where expression was not detected in Equisetum and Osmunda, but was detected in leptopsorangiate ferns [52]. Additional expression studies in diverse fern species as well as knockouts will be necessary to better understand what these genes do in their native context, to further test hypotheses of leaf evolution, and to better understand the differences in connection with the leaf developmental network across ferns.

\section{Materials and Methods}

\subsection{Sampling for the Phylogenetic Analyses of Class I KNOX Genes}

To gain a more detailed evolutionary history of Class I KNOX in ferns and to discover the putative Elaphoglossum Class I KNOX gene copies for our expression studies, we obtained representative species across the fern and lycophyte phylogeny from publicly available databases and by cloning. We included Class I KNOX genes previously published from the lycophytes Selaginella krausiana [10], Huperzia selago and Isoetes tegetiformans [87], and Lycopodium deuterodensum [88]; from the ferns Ceratopteris richardii [32], Elaphoglossum peltatum f. peltatum [33], and Equisetum diffusum [88]. We got these sequences from GenBank, the 1KP plant transcriptome project (http://www.onekp.com, accessed May 2018) databases, or directly from the published papers. BLAST similarity searches (Altschul et al., 1990) in the lycophyte Selaginella moellendorffii genome available in Phytozome (https://phytozome.jgi.doe.gov, last accessed May 2018) were used to identify Class I KNOX copies in S. moellendorffii. BLAST searches were also conducted in the fern genomes of Azolla filiculoides and Salvinia cucullata, available in Fernbase (https://www.fernbase.org/, last accessed May 2019). Further lycophyte and fern sequences were 
obtained using degenerate primers previously published [33]. For the phylogenetic analyses, published sequences from GenBank for the other lineages of vascular plants (gymnosperms and angiosperms) were also included. Class I KNOX Physcomitrium patens sequences available at GenBank were used as outgroups and to root the trees. A list of all sampled species, provenance, and accession numbers is provided in Appendix A (these will be provided during review).

\subsection{Sequence Analysis, Alignment, and Phylogenetic Analysis}

New sequence contigs were assembled using Geneious V. 11 (Biomatters Ltd., New Zealand). Sequences were compiled and cleaned to keep just the open reading frame. Nucleotide sequences were aligned using the online version of MAFFT v.7 [89]. The alignment was refined by hand, using Mesquite V. 3.5 [90], considering protein domains and amino acid motifs that have been reported as conserved for KNOX genes. A matrix that included KNOX, the ELK, and the TALE-HD was used for phylogenetic analyses. Phylogenetic relationships were inferred from the nucleotide data using Bayesian inference (BI). Analyses were performed on CIPRES (http://www.phylo.org) [91]. The best partition scheme was found with PartitionFinder2 [92], for the nucleotides matrix 15 data blocks were defined by dividing the matrix into five regions (KNOX 1 (first KNOX domain), KNOX 1-KNOX 2 (region between KNOX 1 and KNOX 2), KNOX 2 (second KNOX domain), KNOX 2-HD (region between KNOX 2 and the HD), and HD (ELK and TALE-HD domains)), and by dividing each region by codon position. Analyses were performed with nine subsets as estimated by the corrected Akaike Information Criterion (AICc) implemented in PartitionFinder2 (Table S1; see Supplemental Data with this article). For the amino acids matrix, the JTT+I+G model was used as estimated by the corrected Akaike Information Criterion (AICc) implemented in PartitionFinder2 [93]. For both matrices, BI analyses were conducted using MrBAYES 3.2.6 [93]. Two independent runs of 10 million generations were completed, with four chains each (three heated, one cold), using a chain temperature of 0.2 and uniform priors. Trees and parameters were sampled every 1000th generation. Samples corresponding to the initial phase of the Markov chains ( $25 \%$ ) were discarded as burn-in. The applicability of this burn-in value was determined by the inspection of the likelihood scores and effective sample sizes. Post-burn-in trees were combined to obtain a single majority rule consensus tree and the respective posterior probabilities (PPs) of nodes. Trees were depicted using FigTree v1.4.3 (http://tree.bio.ed.ac.uk/software/figtree/).

\subsection{Taxonomic Sampling for Gene Expression Studies}

To better understand the molecular genetic basis for the differences in leaf form in ferns, we studied gene expression patterns of Histone $\mathrm{H} 4$ genes (used as a cell division marker) and of Class I KNOX genes in developing leaf primordia of two taxa with simple leaves (E. lloense and E. peltatum f. standleyi) and one taxon with divided leaves (E. peltatum f. peltatum) belonging to the fern genus Elaphoglossum (Figure 1b-d). Additionally, we compared our results of Class I KNOX expression to what is known from similar studies performed in seed plants and lycophytes, in order to better understand what these leaf developmental genes tell us about megaphyll leaf evolution.

For the expression analyses, the material of E. lloense was collected in the field in Ecuador (Vasco 865, NY), and both E. peltatum forms were sourced from specialist fern growers and kept in the Nolen glasshouses at the New York Botanical Garden (NYBG).

\subsection{RNA and DNA Extraction and cDNA Synthesis}

For RNA and DNA extraction, we preserved the material collected in the field in Ecuador in RNAlater (Life Technologies, Carlsbad, CA, USA); for the living plants growing in the NYBG greenhouses, we preserved the material in liquid nitrogen. Total RNA was extracted from sporophyte shoot apices (including the SAM and young leaves), as previously described [94] with some modifications as follows. Approximately $5 \mathrm{~g}$ of tissue was ground to a fine powder in liquid nitrogen with a mortar and pestle. The powder was added to $25 \mathrm{~mL}$ of lysis buffer containing $0.1 \mathrm{M}$ $\mathrm{NaCl}, 50 \mathrm{mM}$ TrisHCl (pH 7.4), $50 \mathrm{mM}$ EDTA ( $\mathrm{pH}$ 8), 2\% SDS, and proteinase K (200 ug/mL), and 
stirred at room temperature for 10-15 $\mathrm{min}$. Cell debris was centrifuged at 10,000 rpm for $5 \mathrm{~min}$, and the supernatant was extracted twice with an equal volume of phenol/chloroform/isoamylalcohol (50:48:2) and once with chloroform/isoamylalcohol (96:4), centrifuging each time at 10,000 rpm for $10 \mathrm{~min}$. A volume of 0.1 of $3 \mathrm{M} \mathrm{NaOAc}$ and 2.5 volumes Ethanol (ETOH) were added to the aqueous phase and centrifuged at 10,000 rpm for $5 \mathrm{~min}$. The pellet was air dried from $5 \mathrm{~min}$ and resuspended in 700 uL DEPC-water. Then, $700 \mathrm{uL}$ of $\mathrm{LiCl}(4 \mathrm{M})$ was added and incubated overnight at $4{ }^{\circ} \mathrm{C}$. The sample was centrifuged at 10,000 rpm for $10 \mathrm{~min}$ at $4{ }^{\circ} \mathrm{C}$, the supernatant was discarded, and the pellet was resuspended in $200 \mathrm{uL}$ DEPC water. Then, $20 \mathrm{uL}$ of NaOAc (3M) and $500 \mathrm{uL}$ ETOH were added and left at $-20{ }^{\circ} \mathrm{C}$ for $30 \mathrm{~min}$. The sample was centrifuged at $10,000 \mathrm{rpm}$ for $10 \mathrm{~min}$ at $4{ }^{\circ} \mathrm{C}$, and then washed with $70 \%$ ETOH made with DEPC water. Finally, the pellet was air dried and resuspended in $20 \mathrm{uL}$ of DEPC water. Samples collected in RNAlater were extracted with the same protocol, but the tissue was ground in the lysis buffer. cDNA was synthesized using Superscipt III (Invitrogen, Carlsbad, CA, USA) according to the manufacturer's instructions.

\subsection{Primer Design and PCR}

Histone H4 and Class I KNOX sequences of the three Elaphoglossum species were isolated by PCR with degenerate primers (01H4f5'ATGTCWGGMMGRGGWAAGGGAGG, 01H4r5' CCRAAD CCRTARAGVGTHCKKCC, 01KNOXf5' CCBGARCTBGACMABTTYATGG, and 02KN OXr5' CCAGT GSCKYTTCCKYTGRTTDATRAACC) and by 5' RACE (Clontech Laboratories Inc., Mountain View, CA, USA) according to the manufacturer's protocol. PCR reactions used cDNA as template and forward and reverse degenerate primers. PCR products were cleaned and cloned directly into the pCRII vector (TOPO TA cloning kit, Invitrogen, Carlsbad, CA, USA). A total of 20-30 colonies were grown in LB culture and plasmid DNA was isolated. Clones representing different banding patterns were sequenced by the Sanger method (Macrogen, USA) and BLAST was used to compare sequences in NCBI.

\subsection{In Situ Hybridization}

Tissues were fixed in the field for E. lloense or at NYBG for both E. peltatum forms in formaldehyde acetic acid for $2-4 \mathrm{~h}$, and then dehydrated through a graded ethanol series to $100 \%$ ethanol. Tissue was embedded in Paraplast X-tra (Fisher brand) and sectioned on a microtome to $10 \mathrm{um}$. Sections were placed on ProbeOn Plus slides (Fisherbrand, Pittsburgh, PA). Gene-specific fragments for all the recovered Elaphoglossum H4 and Class I KNOX copies (see results) were amplified using primers designed for this study (Figure S1 and Table S2). Digoxigenin labeled gene-specific probes were generated according to the manufacturer's instructions (Roche Applied Science, Indianapolis, IN, USA). Slides were left on a hot plate at $42{ }^{\circ} \mathrm{C}$ overnight. Treatment of cells and tissues prior to hybridization was performed as previously described [95]. Hybridizations, washes, blocking, antibody incubation, and detection were performed as in Torres et al. [96], except hybridization was performed overnight in $50 \%$ formamide humidified box at $55{ }^{\circ} \mathrm{C}$. Sense probes were used as negative controls on pairs of slides and run in parallel with antisense probes. Sense probes gave no staining to illustrate that none of the tissue was sticky, as already indicated by different expression patterns exhibited by antisense KNOX and H4. Slides were examined and photographed on a Zeiss Axioskop microscope equipped with a Zeiss Axiocam digital camera.

Supplementary Materials: Supplementary Materials can be found at http://www.mdpi.com/1422-0067/21/15/ 5180/s1. Table S1. Best partition scheme and models for the aligned Class I KNOX matrix as estimated by the corrected Akaike Information Criterion (AICc) implemented in PartitionFinder2. Table S2. Forward and reverse primers designed for in-situ hybridizations. Figure S1. (a) Nucleotide and (b) amino acid alignment of the three copies of Class I KNOX genes recovered in ferns. In the nucleotide alignment, dark and white bars show the location of the forward and reverse primers respectively, designed for in-situ hybridizations. Figure S2. Scanning electron microscope images of shoot apices of Elaphoglossum peltatum $\mathrm{f}$. peltatum showing massive presence of scales over the SAM and coiled young leaf primordia. (a) Shoot apex completely covered by scales. (b) Stage 3, leaf primordium completely covered by scales. (c) Stage 4 leaf primordium with coiled subdivisions (pinnae) completely covered by scales. (d) Late Stage 4 leaf primordium, only at this stage of development is lamina visible. 
Star indicates the putative location of the SAM; L, leaf primordium; P, pinna; scales are highlighted with dotted lines. Figure S3. Additional expression of Class I KNOX genes during leaf development in species of the fern genus Elaphoglossum with simple and divided leaves. $(\mathrm{a}, \mathrm{b})$ Elaphoglossum peltatum $\mathrm{f}$. standleyi (simple leaves), expression of EpsC1KNOX1, longitudinal sections through the SAM, and/or leaf primordia. (a) Expression throughout the entire apical dome of the SAM and procambium, including expression in the incipient leaf primordium (Stage 0). (b) Expression throughout the entire young leaf primordium including the leaf apical initial (LAI); expression in the root apical meristem (RAM). (c-g) Elaphoglossum peltatum f. peltatum (divided leaves). (c-f) Expression patterns of EppC1KNOX1, longitudinal sections through the SAM, and/or leaf primordia. (c) Expression throughout the entire apical dome of the SAM and procambium, including expression in the incipient leaf primordium (Stage 0). (d) Expression throughout the entire young leaf primordium including the LAI. (e) Expression throughout the entire apical dome of the SAM and procambium; expression in the root apical meristem (RAM). (f) Expression throughout the entire apical dome of the SAM and procambium, including expression in the incipient leaf primordium; expression in the apical region of an older leaf primordium (right). (e) Expression of EppC2KNOX1 in the leaf primordium, procambium and root primordium. Black arrowheads, leaf primordia; brackets, LAI; stars, SAM; white arrows = root primordium; white arrowheads, procambium; bars $=40 \mathrm{um}$.

Author Contributions: Conceptualization, A.V. and B.A.A.; Methodology, A.V. and B.A.A.; Investigation, A.V. and B.A.A.; Data Curation, A.V.; Writing-Original Draft Preparation, A.V.; Writing-Review \& Editing, A.V. and B.A.A.; Visualization, A.V.; Funding Acquisition, A.V. and B.A.A. All authors have read and agreed to the published version of the manuscript.

Funding: This research was funded by National Science Foundation DEB-1020443 to B.A.A. and from Programa UNAM-DGAPA-PAPIIT IA201416 to A.V.

Acknowledgments: Catalina Quintana, Renato Valencia, Hugo Navarrete, and the herbarium personnel of the Catholic University of Quito (QCA) were enormously helpful during our field work in Ecuador, where we collected E. lloense and E. tripartitum. We thank the staff of the Nolen glasshouses at the New York Botanical Garden for taking care of some of the species used for isolating Class I KNOX and H4 genes and for in situs, and to Charles Alford (www.rareferns.com) for donating plants of E. peltatum $\mathrm{f}$. standleyi. Tynisha Smalls assisted with the molecular work at NY. Advice and discussions with Robbin Moran were instrumental for this project. Insights from Dennis Stevenson greatly helped with interpreting some of the results. Thanks also to the anonymous reviewers and the associated editor for their time and suggestions.

Conflicts of Interest: The authors declare no conflict of interest.

\section{Abbreviations}

$\begin{array}{ll}\text { C1KNOX } & \text { Class I KNOTTED1-like HOMEOBOX } \\ \text { LAI } & \text { Leaf Apical Initial } \\ \text { LAM } & \text { Leaf Apical Meristem } \\ \text { MM } & \text { Marginal Meristem } \\ \text { RAM } & \text { Root Apical Meristem } \\ \text { SAM } & \text { Shoot Apical Meristem }\end{array}$

\section{Appendix A}

Class I KNOX sequences used in this study. The information is presented in the following order: Lineage, species, name of the sequence in the tree of Figure 2, database, accession number. The first instance of a lineage and species is given in bold. Sequences MT680030- MT680042 are new sequences generated for this study.

Bryophytes: Physcomitrium patens (Hedw.) Bruch \& Schimp., Physcomitrella_PpMKN2, NCBI, XM_001758540. Physcomitrella_PpMKN4, NCBI, XM_001781425. Physcomitrella_PpMKN5, NCBI, XM_001778213. Lycophytes: Huperzia selago (L.) Bernh. ex Schrank \& Mart., Huperzia_HsKNOX1_1, NCBI, KX761181. Huperzia_HsKNOX1_2, NCBI, KX761182. Huperzia squarrosa (G. Forst.) Trevis., Huperzia_HsqC1KNOX1, NCBI, MT680030. Isoetes riparia Engelm. ex A. Braun, Isoetes_IrC1KNOX1, NCBI, MT680031. Isoetes_IrC1KNOX2, NCBI, MT680032. Isoetes tegetiformans Rury, Isoetes_ItKNOX1, 1KP, PKOX_2098898. Lycopodium deuterodensum Herter, Lycopodium_LdC1KNOX1, 1KP, PQTO-2010435. Lycopodium_LdC1KNOX2, 1KP, PQTO-2081329. Selaginella kraussiana (Kunze) A. Braun, Selaginella_SkKNOX1, NCBI, AY667449. Selaginella_SkKNOX2, NCBI, AY667450. Selaginella moellendorffii Hieron., Selaginella_SmKNOX1, NCBI, XM_002988279. Selaginella_SmKNOX2, NCBI, XM_002977393. Gymnosperms, Picea abies (L.) H. Karst., Picea_PaHBK1, NCBI, AF063248. Picea_PaHBK2, NCBI, AF483277. Picea_PaHBK3, NCBI, AF483278. Picea_PaHBK4, NCBI, DQ257981 \& DQ258006. Pinus taeda L., Pinus_PtKN1, NCBI, AY680402. Pinus_PtKN2, NCBI, AY680403. Pinus_PtKN3, NCBI, AY680404. Pinus_PtKN4, NCBI, AY680387 \& AY680398. Angiosperms, Arabidopsis thaliana (L.) Heynh., Arabidopsis_AtSTM, NCBI, NM_104916. Arabidopsis_AtKNAT1/BP, NCBI, U14174.1. Arabidopsis_AtKNAT2, NCBI, NM_105719. Arabidopsis_AtKNAT6, NCBI, NM_102187. Zea mays L., Zea_ZmKn-1, NCBI, X61308. Zea_ZmrRS1, NCBI, L44133. Zea_Zmlg3, NCBI, NM_001112038. Zea_ZmKNOX5/lg4b, NCBI, NM_001111615.2. Ferns, Angiopteris evecta (G. Forst.) Hoffm., Angiopteris_AeC1KNOX1, NCBI, MT680033. Azolla filiculoides 
Lam., Azolla_AfC1KNOX1A, FernBase, Azfi_s2491.g111832 and Azfi_s0350.g066570. Azolla_AfC1KNOX1B, FernBase, Azfi_s0006.g009595. Azolla_AfC1KNOX3, FernBase, Azfi_s2342.g110698 and Azfi_s0350.g066569. Ceratopteris richardii Brongn., Ceratopteris_CrKNOX1, NCBI, AB043954. Ceratopteris_CrKNOX2, NCBI, AB043956. Cyathea dregei Kunze, Cyathea_CdC1KNOX2, NCBI, MT680034. Elaphoglossum ciliatum (C. Presl) T. Moore, Elaphoglossum_EcC1KNOX2, NCBI, MT680035. Elaphoglossum lloense (Hook.) T. Moore, Elaphoglossum_EllC1KNOX2, NCBI, MT680036. Elaphoglossum peltatum f. peltatum (Sw.) Urb., Elaphoglossum_EppC1KNOX1, NCBI, KT382287. Elaphoglossum_EppC1KNOX2, NCBI, KT382288. Elaphoglossum peltatum f. standleyi (Maxon) Mickel, Elaphoglossum_EpsC1KNOX2, NCBI, MT680037. Elaphoglossum_EpsC1KNOX1, NCBI, MT680038. Elaphoglossum tripartitum (Hook. \& Grev.) Mickel, Elaphoglossum_EtC1KNOX2, NCBI, MT680039. Equisetum diffusum D. Don, Equisetum _EdKNOX1A, 1kp, CAPN-2006400. Equisetum_EdKNOX1B, 1kp, CAPN-2006401. Marsilea minuta L., Marsilea_MmC1KNOX2, NCBI, MT680040. Marsilea_MmC1KNOX3, NCBI, MT680041. Pilularia globulifera L., Pilularia_PgC1NOX2, NCBI, MT680042. Salvinia cucullata Roxb., Salvinia_ScC1KNOX1A, FernBase, Sacu_v1.1_s0115.g020964. Salvinia_ScC1KNOX1B, FernBase, Sacu_v1.1_s0011.g005308. Salvinia_ScC1KNOX3, FernBase, Sacu_v1.1_s0091.g018785.

\section{Appendix B}

Histone H4 sequences recovered in this study. The information is presented in the following order: species, name of the sequence, database, accession number. The first instance of a lineage and species is given in bold. All sequences are newly generated for this study.

Elaphoglossum lloense (Hook.) T. Moore, EllH4, NCBI, MT776685. Elaphoglossum peltatum f. peltatum (Sw.) Urb., EppH4, NCBI, MT776686. Elaphoglossum peltatum f. standleyi (Maxon) Mickel, EpsH4, NCBI, MT776687.

\section{References}

1. Gifford, E.M.; Foster, A.S. Morphology and Evolution of Vascular Plants, 3rd ed.; W.H. Freeman and Co.: New York, NY, USA, 1989; ISBN 0716719460.

2. Beerling, D.J. Leaf Evolution: Gases, Genes and Geochemistry. Ann. Bot. 2005, 96, 345-352. [CrossRef] [PubMed]

3. Boyce, C.K.; Knoll, A.H. Evolution of developmental potential and the multiple independent origins of leaves in Paleozoic vascular plants. Paleobiology 2002, 28, 70-100. [CrossRef]

4. Boyce, C.K. The evolution of plant development in a paleontological context. Curr. Opin. Plant Biol. 2010, 13, 102-107. [CrossRef] [PubMed]

5. Sanders, H.; Rothwell, G.W.; Wyatt, S.E. Key morphological alterations in the evolution of leaves. Int. J. Plant Sci. 2009, 170, 860-868. [CrossRef]

6. Tomescu, A.M.F. Megaphylls, microphylls and the evolution of leaf development. Trends Plant Sci. 2009, 14, 5-12. [CrossRef]

7. Vasco, A.; Moran, R.C.; Ambrose, B.A. The evolution, morphology, and development of fern leaves. Front. Plant Sci. 2013, 4, 345. [CrossRef]

8. Harrison, C.J.; Morris, J.L. The origin and early evolution of vascular plant shoots and leaves. Philos. Trans. R. Soc. B Biol. Sci. 2017, 373, 20160496. [CrossRef]

9. Bharathan, G.; Goliber, T.E.; Moore, C.; Kessler, S.; Pham, T.; Sinha, N.R. Homologies in leaf form inferred from KNOXI gene expression during development. Science 2002, 296, 1858-1860. [CrossRef]

10. Harrison, C.J.; Corley, S.B.; Moylan, E.C.; Alexander, D.L.; Scotland, R.W.; Langdale, J.A. Independent recruitment of a conserved developmental mechanism during leaf evolution. Nature 2005, 434, 509-514. [CrossRef]

11. Floyd, S.K.; Bowman, J.L. Gene expression patterns in seed plant shoot meristems and leaves: Homoplasy or homology? J. Plant Res. 2010, 123, 43-55. [CrossRef]

12. Bar, M.; Ori, N. Compound leaf development in model plant species. Curr. Opin. Plant Biol. 2015, $23,61-69$. [CrossRef]

13. Du, F.; Guan, C.; Jiao, Y. Molecular Mechanisms of Leaf Morphogenesis. Mol. Plant 2018, 11, 1117-1134. [CrossRef] [PubMed]

14. Vollbrecht, E.; Veit, B.; Sinha, N.R.; Hake, S. The developmental gene Knotted-1 is a member of a maize homeobox gene family. Nature 1991, 350, 241-243. [CrossRef] [PubMed]

15. Jackson, D.; Veit, B.; Hake, S. Expression of maize KNOTTED1 related homeobox genes in the shoot apical meristem predicts patterns of morphogenesis in the vegetative shoot. Development 1994, 120, 405-413. 
16. Kerstetter, R.; Vollbrecht, E.; Lowe, B.; Veit, B.; Yamaguchi, J.; Hake, S. Sequence analysis and expression patterns divide the maize knotted1-like homeobox genes into two classes. Plant Cell 1994, 6, 1877-1887.

17. Lincoln, C.; Long, J.; Yamaguchi, J.; Serikawa, K.; Hake, S. A knotted1-like homeobox gene in Arabidopsis is expressed in the vegetative meristem and dramatically alters leaf morphology when overexpressed in transgenic plants. Plant Cell 1994, 6, 1859-1876.

18. Endrizzi, K.; Moussian, B.; Haecker, A.; Levin, J.Z.; Laux, T. The SHOOT MERISTEMLESS gene is required for maintenance of undifferentiated cells in Arabidopsis shoot and floral meristems and acts at a different regulatory level than the meristem genes WUSCHEL and ZWILLE. Plant J. 1996, 10, 967-979. [CrossRef]

19. Long, J.A.; Moan, E.I.; Medford, J.I.; Barton, M.K. A member of the KNOTTED class of homeodomain proteins encoded by the STM gene of Arabidopsis. Nature 1996, 379, 66-69. [CrossRef]

20. Nishimura, A.; Tamaoki, M.; Sato, Y.; Matsuoka, M. The expression of tobacco knotted1-type class 1 homeobox genes correspond to regions predicted by the cytohistological zonation model. Plant J. 1999, 18, 337-347. [CrossRef]

21. Reiser, L.; Sanchez-Baracaldo, P.; Hake, S.; Sánchez-Baracaldo, P. Knots in the family tree: Evolutionary relationships and functions of knox homeobox genes. Plant Mol. Biol. 2000, 42, 151-166. [CrossRef]

22. Hay, A.; Tsiantis, M. The genetic basis for differences in leaf form between Arabidopsis thaliana and its wild relative Cardamine hirsuta. Nat. Genet. 2006, 38, 942-947. [CrossRef]

23. Kimura, S.; Koenig, D.; Kang, J.; Yoong, F.Y.; Sinha, N.R. Natural variation in leaf morphology results from mutation of a novel KNOX gene. Curr. Biol. 2008, 672-677. [CrossRef] [PubMed]

24. Hareven, D.; Gutfinger, T.; Parnis, A.; Eshed, Y.; Lifschitz, E. The making of a compound leaf: Genetic manipulation of leaf architecture in tomato. Cell 1996, 84, 735-744. [CrossRef]

25. Chen, J.J.; Janssen, B.J.; Williams, A.; Sinha, N.R. A gene fusion at a homeobox locus: Alterations in leaf shape and implications for morphological evolution. Plant Cell 1997, 9, 1289-1304. [PubMed]

26. Janssen, B.J.; Williams, A.; Chen, J.J.; Mathern, J.; Hake, S.; Sinha, N.R. Isolation and characterization of two knotted-like homeobox genes from tomato. Plant Mol. Biol. 1998, 36, 417-425. [CrossRef] [PubMed]

27. Sinha, N.R.; Williams, R.E.; Hake, S. Overexpression of the maize homeo box gene, KNOTTED-1, causes a switch from determinate to indeterminate cell fates. Genes Dev. 1993, 7, 787-795. [CrossRef] [PubMed]

28. Ori, N.; Eshed, Y.; Chuck, G.; Bowman, J.L.; Hake, S. Mechanisms that control knox gene expression in the Arabidopsis shoot. Development 2000, 127, 5523-5532.

29. Koenig, D.; Bayer, E.; Kang, J.; Kuhlemeier, C.; Sinha, N.R. Auxin patterns Solanum lycopersicum leaf morphogenesis. Development 2009, 136, 2997-3006. [CrossRef]

30. Sundås-Larsson, A.; Svenson, M.; Liao, H.; Engström, P. A homeobox gene with potential developmental control function in the meristem of the conifer Picea abies. Proc. Natl. Acad. Sci. USA 1998, 95, 15118-15122. [CrossRef]

31. Pham, T.; Sinha, N.R. Role of Knox Genes in Shoot Development of Welwitschia mirabilis. Int. J. Plant Sci. 2003, 164, 333-343. [CrossRef]

32. Sano, R.; Juárez, C.M.; Hass, B.; Sakakibara, K.; Ito, M.; Banks, J.A.; Hasebe, M.; Juarez, C.M. KNOX homeobox genes potentially have similar function in both diploid unicellular and multicellular meristems, but not in haploid meristems. Evol. Dev. 2005, 7, 69-78. [CrossRef] [PubMed]

33. Ambrose, B.A.; Vasco, A. Bringing the multicellular fern meristem into focus. New Phytol. 2016, 210, 790-793. [CrossRef]

34. Mickel, J.T.; Smith, A.R. The pteridophytes of Mexico. Mem. N. Y. Bot. Gard. 2004, 88, 1-1055.

35. Vasco, A.; Mickel, J.T.; Moran, R.C. Taxonomic revision of the neotropical species of Elaphoglossum Sect. Squamipedia (Dryopteridaceae). Ann. Missouri Bot. Gard. 2013, 99, 244-286. [CrossRef]

36. Vasco, A.; Lóriga, J.; Rouhan, G.; Ambrose, B.A.; Moran, R.C. Divided leaves in the genus Elaphoglossum (Dryopteridaceae): A phylogeny of Elaphoglossum section Squamipedia. Syst. Bot. 2015, 40, 46-55. [CrossRef]

37. Matos, F.B.; Vasco, A.; Moran, R.C. Elaphoglossum doanense and Elaphoglossum tonduzii: New members of Elaphoglossum Sect. Squamipedia (Dryopteridaceae) and their significance for inferring the evolution of rhizome habit and nest-forming leaves within the genus. Int. J. Plant Sci. 2018, 179, 296-313. [CrossRef]

38. Moran, R.C.; Labiak, P.H.; Sundue, M. Phylogeny and character evolution of the bolbitidoid ferns (Dryopteridaceae). Int. J. Plant Sci. 2010, 171, 547-559. [CrossRef] 
39. Dinneny, J.R.; Yadegari, R.; Fischer, R.L.; Yanofsky, M.F.; Weigel, D. The role of JAGGED in shaping lateral organs. Development 2004, 131, 1101-1110. [CrossRef] [PubMed]

40. von Willdenow, C.L. Species Plantarum. Editio quarta 5; G.C. Nauk: Berlin, Germany, 1810.

41. Christ, H. Monographie des Genus Elaphoglossum. Neue Denkschriften der Allg. Schweizerischen Gesellschaft für die gesammten Naturwissenschaften 1899, 36, 1-159.

42. Morton, C.V. Notes on Elaphoglossum, III. The publication of Elaphoglossum and Rhipidopteris. Am. Fern J. 1955, 45, 11-14. [CrossRef]

43. Gómez, L.D. Contribuciones a la pteridología costarricense. VI. El género Peltapteris Link en Costa Rica. Brenesia 1975, 6, 25-31.

44. Mickel, J.T. Relationships of the dissected elaphoglossoid ferns. Brittonia 1980, 32, 109-117. [CrossRef]

45. Steeves, T.A.; Sussex, I.M. Patterns in Plant Development; Cambridge University Press: New York, NY, USA, 1989.

46. Wardlaw, C.W. Experimental and analytical studies of pteridophytes: XIV. Leaf formation and phyllotaxis in Dryopteris aristata Druce. Ann. Bot. 1949, 13, 163-198. [CrossRef]

47. Saha, B. Morphogenetic studies on the distribution and activities of leaf meristems in ferns. Ann. Bot. 1963, 27, 269-279. [CrossRef]

48. Zurakowski, K.A.; Gifford, E.M. Quantitative studies of pinnule development in the ferns Adaiantum raddiantum and Cheilanthes viridis. Am. J. Bot. 1988, 75, 1559-1570. [CrossRef]

49. Bierhorst, D.W. On the stem apex, leaf initiation and early leaf ontogeny in filicalean ferns. Am. J. Bot. 1977, 64, 125-152. [CrossRef]

50. Bower, F.O. The Ferns (Filicales) Treated Comparatively with a View to Their Natural Classification; Cambridge University Press: Cambridge, UK, 1923.

51. Prigge, M.J.; Otsuga, D.; Alonso, J.M.; Ecker, J.R.; Drews, G.N.; Clark, S.E. Class III homeodomain-leucine zipper gene family members have overlapping, antagonistic, and distinct roles in Arabidopsis development. Plant Cell 2005, 17, 61-76. [CrossRef]

52. Vasco, A.; Smalls, T.L.; Graham, S.W.; Cooper, E.D.; Wong, G.K.-S.; Stevenson, D.W.; Moran, R.C.; Ambrose, B.A. Challenging the paradigms of leaf evolution: Class III HD-Zips in ferns and lycophytes. New Phytol. 2016, 212, 745-758. [CrossRef]

53. PPG I A community-derived classification for extant lycophytes and ferns. J. Syst. Evol. 2016, 54, 560-603.

54. Li, F.-W.; Brouwer, P.; Carretero-Paulet, L.; Cheng, S.; de Vries, J.; Delaux, P.-M.; Eily, A.; Koppers, N.; Kuo, L.-Y.; Li, Z.; et al. Fern genomes elucidate land plant evolution and cyanobacterial symbioses. Nat. Plants 2018, 4, 460-472. [CrossRef]

55. Rothfels, C.J.; Li, F.-W.; Sigel, E.M.; Huiet, L.; Larsson, A.; Burge, D.O.; Ruhsam, M.; Deyholos, M.; Soltis, D.E.; Stewart, C.N.; et al. The evolutionary history of ferns inferred from 25 low-copy nuclear genes. Am. J. Bot. 2015, 102, 1089-1107. [CrossRef] [PubMed]

56. Leebens-Mack, J.H.; Barker, M.S.; Carpenter, E.J.; Deyholos, M.K.; Gitzendanner, M.A.; Graham, S.W.; Grosse, I.; Li, Z.; Melkonian, M.; Mirarab, S.; et al. One thousand plant transcriptomes and the phylogenomics of green plants. Nature 2019, 574, 679-685.

57. Wardlaw, C.W. Experimental studies of the sporophytes of ferns. J. Linn. Soc. London, Bot. 1963, 8, 385-400. [CrossRef]

58. White, R.; Turner, M. Anatomy and development of the fern sporophyte. Bot. Rev. 1995, 61, 281-305. [CrossRef]

59. Imaichi, R. Meristem organization and organ diversity. In Biology and Evolution of Ferns and Lycophytes; Ranker, T.A., Haufler, C.H., Eds.; Cambridge University Press: Cambridge, UK, 2008; pp. 75-103.

60. Bower, F.O. The comparative examination of the meristems of ferns, as a phylogenetic study. Ann. Bot. 1889, 3, 305-392. [CrossRef]

61. Pray, T.R. Ontogeny of the open dichotomous venation in the pinna of the fern Nephrolepis. Am. J. Bot. 1960, 47, 319-328. [CrossRef]

62. Pray, T.R. Ontogeny of the Closed Dichotomous Venation of Regnellidium. Am. J. Bot. 1962, 49, 464-472. [CrossRef]

63. Wardlaw, C.W. Reflections on the unity of the embryonic tissues in ferns. Phytomorphology 1958, 8, 323-327.

64. Gaudet, J.J. Morphology of Marsilea vestita. II. Morphology of the Adult Land and Submerged Leaves. Am. J. Bot. 1964, 51, 591-597. [CrossRef] 
65. Steeves, T.A. A study of the developmental potentialities of excised leaf primordia in sterile culture. Phytomorphology 1961, 11, 346-359.

66. Steeves, T.A. Morphogenetic studies of fern leaves. J. Linn. Soc. London, Bot. 1963, 58, 401-415. [CrossRef]

67. Wardlaw, C.W. Experiments on organogenesis in ferns. Growth 1949, 13, 93-131.

68. Wardlaw, C.W. Phyllotaxis and organogenesis in ferns. Nature 1949, 164, 167-169. [CrossRef]

69. Cutter, E.G. Experimental induction of buds from fern leaf primordia. Nature 1954, 173, 440-441. [CrossRef]

70. Cutter, E.G. Experimental and analytical studies of pteridophytes: XXXIII. The experimental induction of buds from leaf primordia in Dryopteris aristata Druce. Ann. Bot. 1956, 20, 143-165. [CrossRef]

71. White, R. Experimental and developmental studies of the fern sporophyte. Bot. Rev. 1971, 37, 509-540. [CrossRef]

72. Steeves, T.A.; Hicks, G.; Steeves, M.; Retallack, B. Leaf determination in the Fern Osmunda cinnamomea-A reinvestigation. Ann. Bot. 1993, 71, 511-517. [CrossRef]

73. Sanders, H.L.; Darrah, P.R.; Langdale, J. a Sector analysis and predictive modelling reveal iterative shoot-like development in fern fronds. Dev. Cambridge Engl. 2011, 138, 2925-2934. [CrossRef]

74. Plackett, A.R.G.; Di Stilio, V.S.; Langdale, J.A. Ferns: The missing link in shoot evolution and development. Front. Plant Sci. 2015, 6, 972. [CrossRef]

75. Arber, A. The interpretation of leaf and root in the angiosperms. Biol. Rev. 1941, 16, 81-105. [CrossRef]

76. Arber, A. The Natural Philosophy of Plant Form; Cambridge University Press: Cambridge, UK, 1950.

77. Hay, A.; Tsiantis, M. KNOX genes: Versatile regulators of plant development and diversity. Development 2010, 137, 3153-3165. [CrossRef]

78. Barkoulas, M.; Hay, A.; Kougioumoutzi, E.; Tsiantis, M. A developmental framework for dissected leaf formation in the Arabidopsis relative Cardamine hirsuta. Nat. Genet. 2008, 40, 1136-1141. [CrossRef] [PubMed]

79. Blein, T.; Pulido, A.; Vialette-Guiraud, A.; Nikovics, K.; Morin, H.; Hay, A.; Johansen, I.E.; Tsiantis, M.; Laufs, P. A Conserved Molecular Framework for Compound Leaf Development. Science 2008, 322, 1835-1839. [CrossRef] [PubMed]

80. Peng, J.; Chen, R. Auxin efflux transporter MtPIN10 regulates compound leaf and flower development in Medicago truncatula. Plant Signal. Behav. 2011, 6, 1537-1544. [CrossRef] [PubMed]

81. Byrne, M.E. Making leaves. Curr. Opin. Plant Biol. 2012, 15, 24-30. [CrossRef] [PubMed]

82. Reinhardt, D.; Mandel, T.; Kuhlemeier, C. Auxin Regulates the Initiation and Radial Position of Plant Lateral Organs. Plant Cell 2000, 12, 507-518. [CrossRef] [PubMed]

83. Benková, E.; Michniewicz, M.; Sauer, M.; Teichmann, T.; Seifertová, D.; Jürgens, G.; Friml, J. Local, Efflux-Dependent Auxin Gradients as a Common Module for Plant Organ Formation. Cell 2003, 115, 591-602. [CrossRef]

84. Berger, Y.; Harpaz-Saad, S.; Brand, A.; Melnik, H.; Sirding, N.; Alvarez, J.P.; Zinder, M.; Samach, A.; Eshed, Y.; Ori, N. The NAC-domain transcription factor GOBLET specifies leaflet boundaries in compound tomato leaves. Development 2009, 136, 823-832. [CrossRef]

85. Floyd, S.K.; Bowman, J.L. Distinct developmental mechanisms reflect the independent origins of leaves in vascular plants. Curr. Biol. 2006, 16, 1911-1917. [CrossRef]

86. Prigge, M.J.; Clark, S.E. Evolution of the class III HD-Zip gene family in land plants. Evol. Dev. 2006, 8, 350-361. [CrossRef]

87. Evkaikina, A.I.; Berke, L.; Romanova, M.A.; Proux-Wéra, E.; Ivanova, A.N.; Rydin, C.; Pawlowski, K.; Voitsekhovskaja, O.V. The Huperzia selago shoot tip transcriptome sheds new light on the evolution of leaves. Genome Biol. Evol. 2017, 9, 2444-2460. [CrossRef] [PubMed]

88. Frangedakis, E.; Saint-Marcoux, D.; Moody, L.A.; Rabbinowitsch, E.; Langdale, J.A. Nonreciprocal complementation of KNOX gene function in land plants. New Phytol. 2017, 216, 591-604. [CrossRef]

89. Katoh, K.; Standley, D.M. MAFFT multiple sequence alignment software version 7: Improvements in performance and usability. Mol. Biol. Evol. 2013, 30, 772-780. [CrossRef] [PubMed]

90. Maddison, W.P.; Maddison, D.R. Mesquite: A modular System for Evolutionary Analysis. Version 3.61. Available online: http://mesquiteproject.org (accessed on 21 July 2020).

91. Miller, M.A.; Pfeiffer, W.; Schwartz, T. Creating the CIPRES Science Gateway for inference of large phylogenetic trees. In Proceedings of the Gateway Computing Environments Workshop (GCE), New Orleans, LA, USA, 14 November 2010; pp. 1-8. 
92. Lanfear, R.; Frandsen, P.B.; Wright, A.M.; Senfeld, T.; Calcott, B. PartitionFinder 2: New methods for selecting partitioned models of evolution for molecular and morphological phylogenetic analyses. Mol. Biol. Evol. 2017, 34, 772-773. [CrossRef]

93. Ronquist, F.R.; Huelsenbeck, J.P. MrBayes: Bayesian inference of phylogeny. Bioinformatics 2003, 19, $1572-1574$. [CrossRef] [PubMed]

94. Cone, K.C.; Burr, F.A.; Burr, B. Molecular analysis of the maize anthocyanin locus C1. Proc. Natl. Acad. Sci. USA 1986, 83, 9631-9635. [CrossRef]

95. Ambrose, B.A.; Lerner, D.R.; Ciceri, P.; Padilla, C.M.; Yanofsky, M.F.; Schmidt, R.J. Molecular and genetic analyses of the Silky1 gene reveal conservation in floral organ specification between eudicots and monocots. Mol. Cell 2000, 5, 569-579. [CrossRef]

96. Torres, M.-A.; Rigau, J.; Puigdomenech, P.; Stiefel, V. Specific distribution of mRNAs in maize growing pollen tubes observed by whole-mount in situ hybridization with non-radioactive probes. Plant J. 1995, 8, 317-321. [CrossRef]

(C) 2020 by the authors. Licensee MDPI, Basel, Switzerland. This article is an open access article distributed under the terms and conditions of the Creative Commons Attribution (CC BY) license (http://creativecommons.org/licenses/by/4.0/). 